\title{
Conservation of Britain's biodiversity: Hieracium angustatiforme, Small-leaved Hawkweed (Asteraceae)
}

\author{
Timothy C.G. Rich \\ Cardiff, U.K.
}

Corresponding author: tim_rich@sky.com

This pdf constitutes the Version of Record published on $26^{\text {th }}$ July 2021

\begin{abstract}
The conservation status of Hieracium angustatiforme P.D. Sell \& C. West (Asteraceae), Small-leaved Hawkweed, has been assessed. It is a rare endemic restricted to the Brecon Beacons, Wales. Only one population of c.330-430 plants is known in Craig Cerrig-gleisiad National Nature Reserve, and it has not been refound at three other sites. Hieracium angustatiforme is assessed as 'Critically Endangered' under IUCN (2001) threat criteria.
\end{abstract}

Keywords: Critically endangered; endemic; IUCN threat category; Wales.

\section{Introduction}

Hieracium angustatiforme P.D. Sell \& C. West (Asteraceae), Small-leaved Hawkweed, is a rare endemic restricted to the Brecon Beacons, Wales (Sell \& Murrell, 2006; McCosh \& Rich, 2018; Rich, 2020). It was listed in Section 42 of the Natural Environment and Rural Communities Act 2006 as a priority species which placed a duty on public bodies in Wales to conserve it. Section 42 was directly replaced in 2016 by Section 7 of the Environment (Wales) Act 2016 which placed a duty on Welsh Ministers to take all reasonable steps to maintain and enhance it, and encourage others to take such steps. To date, despite being of 'principal importance for the purpose of maintaining and enhancing biodiversity in Wales' since 2006, no research or conservation work has been carried out on this species. The aim of this paper is to present a first assessment of its conservation status.

Hieracium angustatiforme was first collected by A. Ley on 16 August 1893 at the head of Glyn Collwng and was initially named as $H$. callistophyllum F.J. Hanbury (CGE). The following year plants collected by W.A. Shoolbred (probably with A. Ley) on 16 August 1894 were named as a 'weak form' of H. caesium Fr. by F.J. Hanbury (Linton, 1895, page 455; BM, CGE, NMW). Further plants were collected by A. Ley in 1900 and were then named by the Scandinavian expert C.J. Lindeberg as his species $H$. angustatum Lindeb., and were distributed as no. $150 \mathrm{H}$. angustatum in the Set of British hawkweeds (1896 etc.) (BM, CGE, NMW, OXF, etc.). Linton (1905) expressed some doubts about conspecificity of Welsh plants and those from elsewhere in Britain with the Scandinavian type but accepted the name on the basis of Lindeberg's own attribution. Ley (1909) was also unsure about the name $H$. angustatum and suggested the Taf Fechan plants were either $H$. nitidum Backh. fil., var. siluriense F. Hand. (= H. siluriense (F. Hanb.) P.D. Sell) or H. caesium auct. 
angl. Pugsley (1948) also included British plants under $H$. angustatum but noted that they were not typical, the Taf Fechan plants in particular differing from Scandinavian $H$. angustatum in having basal leaves with ciliate hairs along the margins. Finally, the South Wales plants were described as a new endemic species by Sell \& West (1955) based on material collected in 1953 at Craig Cerrig-gleisiad, Breconshire (CGE).

Hieracium angustatiforme is a member of Hieracium section Stelligera Zahn which contains over 50 species in Britain and Ireland (Sell \& Murrell, 2006). It forms a closely related group with $H$. cacuminum sensu lato in South Wales and $H$. angustatum (Lindeb.) Lindeb. from the Lake District (Sell \& West 1968). It is most closely related to H. siluriense (F. Hanb.) P.D. Sell, which also grows in the same area, and from which it differs principally in having few stellate hairs on the narrower (1.0-1.2 mm wide) involucral bracts (frequent stellate hairs towards the base of the 1.0-1.7 mm wide involucral bracts in $H$. siluriense); further characters are given in Table 1. It differs from H. cacuminum (A. Ley) A. Ley in having 0-2 stem leaves (4-6 stem leaves in $H$. cacuminum; Rich \& Smith, 2007). It differs from $H$. angustatum in having few stellate hairs on the bracts (many stellate hairs in $H$. angustatum; the conspecificity of the Lake District plants with Scandinavian material should be reviewed).

Table 1. Differences between Hieracium angustatiforme and $\boldsymbol{H}$. siluriense (after Sell \& Murrell 2006).

\begin{tabular}{|l|l|l|}
\hline Character & H. angustatiforme & H. siluriense \\
\hline Stems & $\begin{array}{l}\text { Some simple hairs below, few } \\
\text { stellate hairs above }\end{array}$ & $\begin{array}{l}\text { Numerous simple hairs below, } \\
\text { numerous stellate hairs above }\end{array}$ \\
\hline Basal leaves & $\begin{array}{l}2-7 \times 1-2 \mathrm{~cm}, \text { dull medium } \\
\text { green above, sharp, apiculate } \\
\text { teeth }\end{array}$ & $\begin{array}{l}2.5-9 \times 2-4 \mathrm{~cm} \text {, bright green } \\
\text { above, entire to sharply } \\
\text { dentate with small and well- } \\
\text { spaced teeth }\end{array}$ \\
\hline $\begin{array}{l}\text { Involucral } \\
\text { bracts }\end{array}$ & $\begin{array}{l}\text { 4-10 } \times 1.0-1.2 \mathrm{~mm} \text {, subacute, } \\
\text { with a few stellate hairs on } \\
\text { the margins (numerous simple } \\
\text { and few glandular hairs also } \\
\text { present) }\end{array}$ & $\begin{array}{l}\text { 4-11 } \times 1.0-1.5(-1.7) \mathrm{mm}, \\
\text { obtuse to subacute, with } \\
\text { stellate hairs frequent on the } \\
\text { margins towards the base } \\
\text { (numerous simple and few } \\
\text { glandular hairs also present) }\end{array}$ \\
\hline Receptacle pits & $\begin{array}{l}\text { Shortly dentate (rarely one or } \\
\text { two subulate dentate teeth } \\
\text { present) }\end{array}$ & Subulate-dentate \\
\hline
\end{tabular}

Hieracium angustatiforme is characterised as being slender with narrow, typically elliptic-lanceolate, sharply toothed, weakly glaucous rosettes leaves, $0-1(-2)$ smaller stem leaves, $1-4(-7)$ capitula on 1 or more stems, small heads often only $2.5(-3$ ?) $\mathrm{cm}$ across on long peduncles, involucral bracts narrow (1.0-1.2 $\mathrm{mm}$ wide), more or less acute, with numerous simple hairs, a few short glandular hairs and a few stellate hairs, and yellow styles (Sell \& Murrell, 2006; Figs. 1-3). In the field, the slender plants with small elliptic-lanceolate, toothed leaves and small heads are distinctive. 


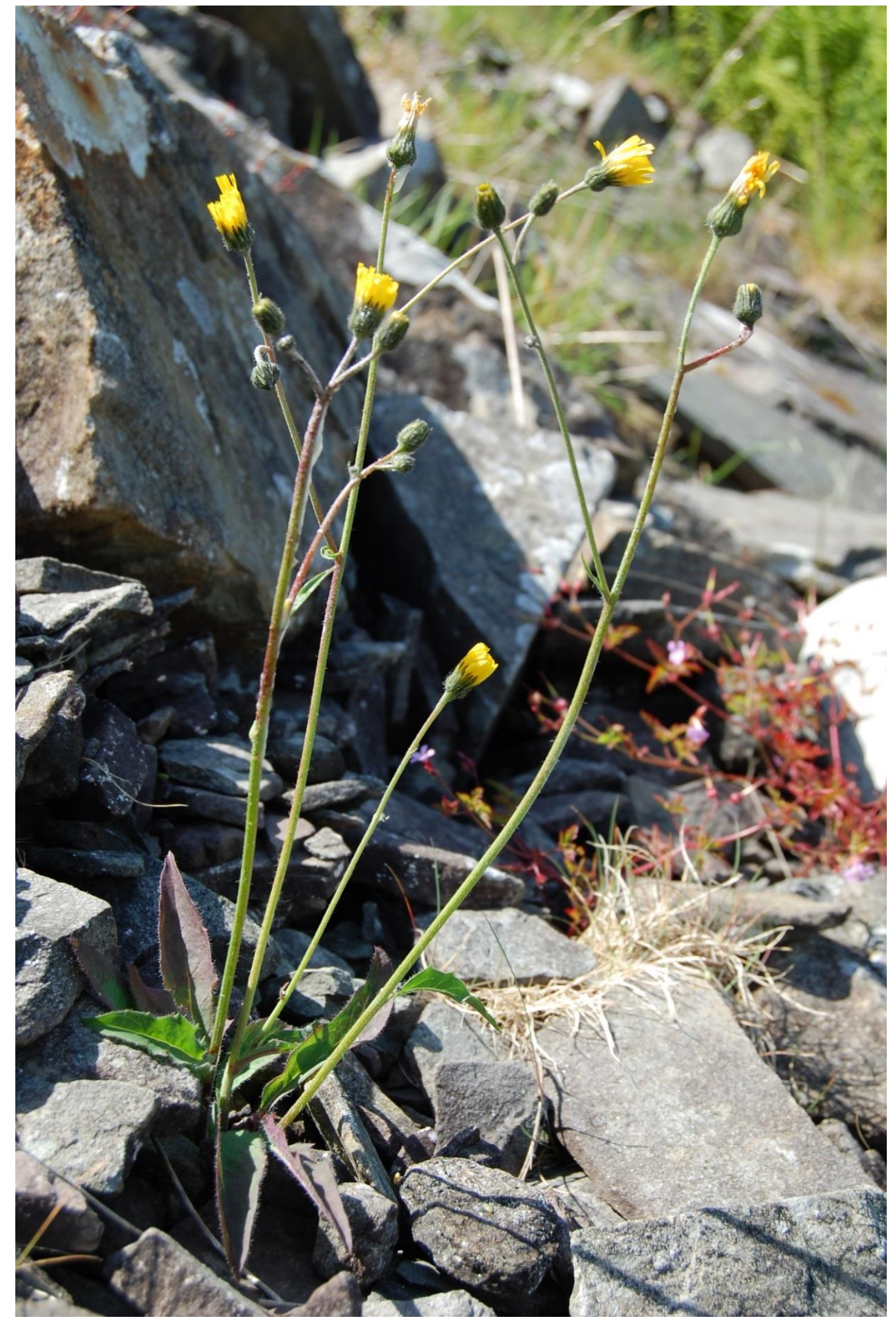

Figure 1. Hieracium angustatiforme plant on basic scree, Craig Cerrig-gleisiad, 23 June 2010. 

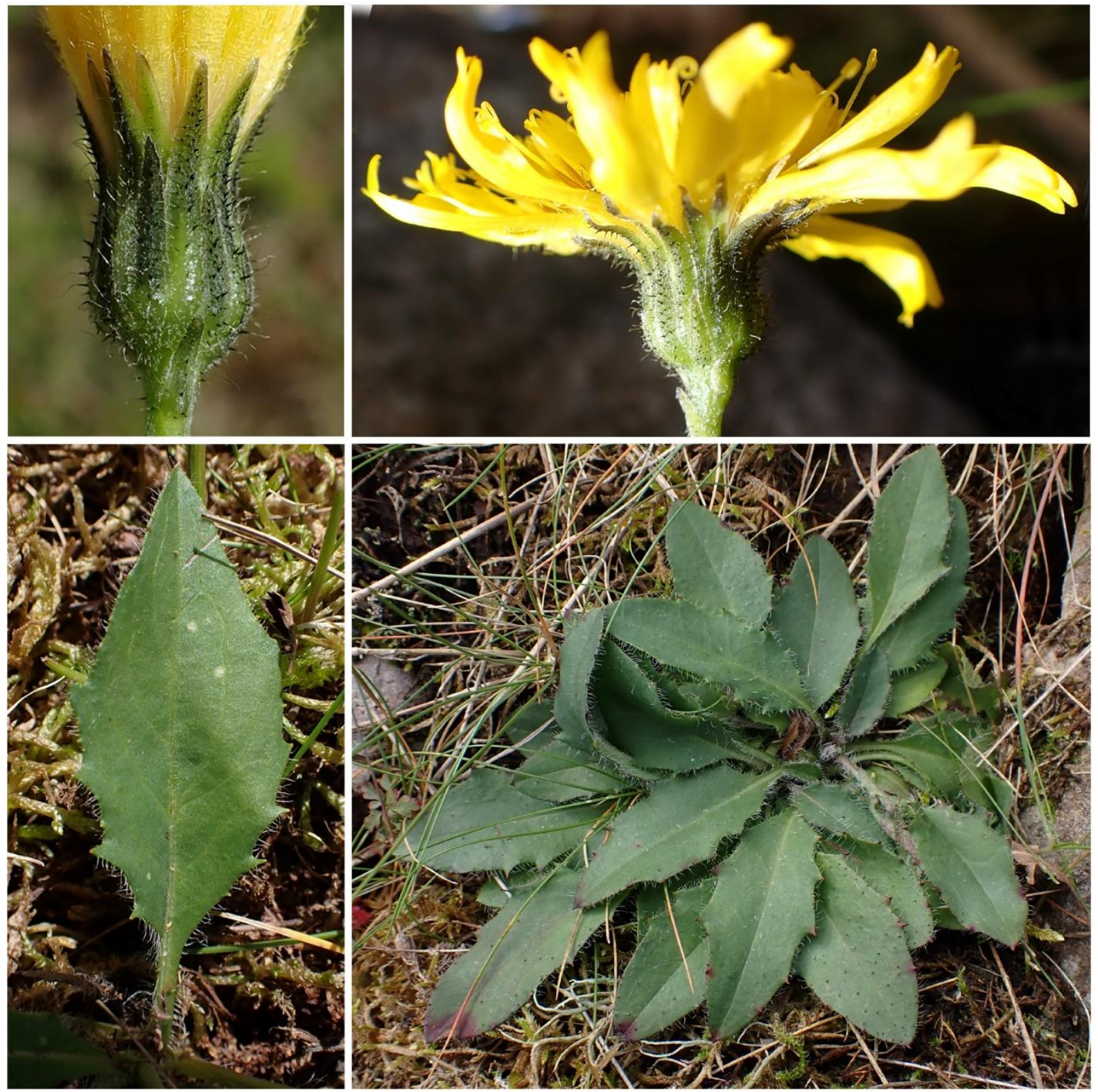

Figure 2. Details of Hieracium angustatiforme capitula and leaves, Craig Cerriggleisiad, 23 June 2010.

\section{Distribution}

Historical records were compiled from herbaria (BM, CGE, NMW, OXF), literature and the Hieracium database maintained by D.J. McCosh (October 2020 version); the records are summarised in Appendix 1. The historical records indicate it has been recorded in four sites, which are listed from west to east below. These have been searched sporadically between 2003 and 2020 usually whilst looking for other Hieracium species.

\section{Craig Cwm-du (Craig Du)}

It was collected once in the small gully 'above Craig Du' on 24 July 1899 by A. Ley. Ley also visited Craig Cerrig-gleisiad on the same day, so this is assumed to be the eastern gully (Nant Cwm Du) at C.SN951219 which has much suitable habitat (and at least three species of Hieracium) rather than the small streams immediately south 
of Craig Cwm-du. It was not refound in September 2020 but could still be present. Craig Cwm-du is part of Craig Cerrig-gleisiad National Nature Reserve (see below) but is $c .0 .5-1 \mathrm{~km}$ to the west with different management so is treated as a separate locality (these sites were combined in McCosh \& Rich, 2018).

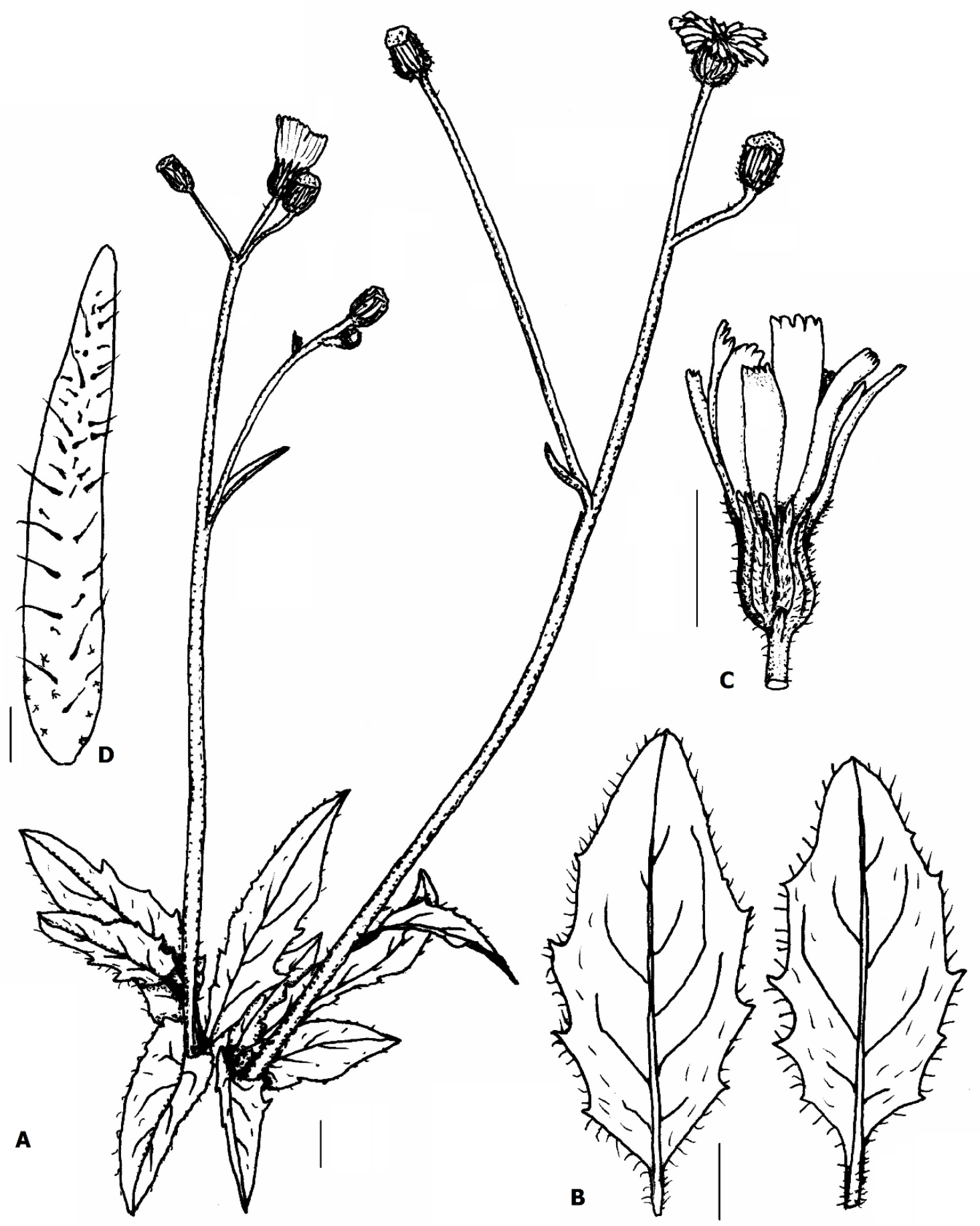

Figure 3. Line illustration of Hieracium angustatiforme. A, plant. B, basal rosette leaves. C, capitulum. $D$, involucral bract. Scale bars $A-C=1 \mathrm{~cm} . D=1 \mathrm{~mm}$. 
Craig Cerrig-gleisiad (Craig Gledsiau) National Nature Reserve (NNR)

The historical records indicate it was found between 1899 and 1958 on cliffs and in the main gully up to $610 \mathrm{~m}$. The SN961218 grid reference cited on the holotype is in the middle of a large cliff and presumably refers to the lower accessible rocks as P.D. Sell did not rock climb; these rocks seem relatively acidic and plants have not been refound, and no plants have been found on the band of more calcareous sandstone below at SN96242189.

In 2003 , one subpopulation was refound in very small quantity on a rocky slope below a calcareous Old Red Sandstone outcrop c. $200 \mathrm{~m}$ north of the holotype location. In 2010, following removal of sheep grazing in the early 2000 s from the NNR, c.50 plants were again found on the rocky slope with a second subpopulation of 27 plants on the scree below. In July and September 2020, the subpopulation on the screes had expanded to 300-400 plants with many small rosettes (no plants were confirmed on the rocky slope due to the abundance of Hieracium rosettes of other species but it was very likely to still be present), the third subpopulation of about 30 plants was refound at the top of the main gully where it was collected in 1958, and another new subpopulation found $200 \mathrm{~m}$ east, $10 \mathrm{~m}$ below the top path.

\section{Taf Fechan}

The 1894-1908 historical records lack sufficient detail to be sure of where they were located, most records simply referred to 'Taf Fechan'. One A. Ley record cited it from a wooded, ferny stream bank in the upper Taf Fechan, other records simply state mountain pastures or rocky banks by streams. It is assumed these collections were made from the Taf Fechan valley above Torpantau as Ley cited that name for other Hieracium records.

The Taf Fechan now has extensive forestry or heavily sheep-grazed moorland and despite visits in 1999 and 2004, it has not been refound (the closely related $H$. siluriense was collected at Neuadd Reservoir in 2004).

\section{Glyn Collwng}

The 1892-1908 historical records indicate it occurred at the head of Glyn Collwng on stream banks and in the enclosure above the railway tunnel. This valley is also now forestry or heavily sheep-grazed moorland and the tunnel portal is heavily scrubbed over (the railway closed in 1964). It has not been refound.

\section{Life cycle and ecology}

Hieracium angustatiforme is a perennial which can flower annually once mature. It is not known how long the plants live, but one lived for at least five years in cultivation in Cardiff 2003-2007. It flowers mainly from mid June to mid August; in September 2020, some plants in Craig Cerrig-Gleisiad recovering from grazing were still flowering. Like most British Hieracium species, it is probably apomictic and polyploid (Sell \& Murrell, 2006 state it is apomictic but this was not actually tested). Seed is set about a month after flowering. Seeds have a pappus and are wind-dispersed.

Its habitats are cliffs, rocks, calcareous scree and small scale land slips, all with open vegetation on freely-drained and probably weakly base-rich soils. The only constantly associated species recorded is Festuca ovina though only a few quadrat data are available (Table 2). In terms of the National Vegetation Classification 
(Rodwell, 1991-2000), the communities on the landslips and rocky banks are open CG10 Festuca ovina-Agrostis capillaris-Thymus praecox grassland, but those on the open basic scree do not fit the National Vegetation Classification well.

Table 2. Species associated with Hieracium angustatiforme in four $1 \mathbf{~ m}^{2}$ quadrats at Craig Cerrig-Gleisiad, 26 September 2020. Figures are Domin cover values estimated by eye. Quadrats 1-3 on scree SN961220, 500 m altitude. Quadrat 4 on slip at top of gully SN961217, $610 \mathrm{~m}$ altitude.

\begin{tabular}{|l|c|c|c|c|c|}
\hline Species & $\mathbf{1}$ & $\mathbf{2}$ & $\mathbf{3}$ & $\mathbf{4}$ & Constancy \\
\hline Hieracium angustatiforme & 2 & 3 & 3 & 3 & IV \\
\hline Festuca ovina & 4 & 8 & 3 & 5 & IV \\
\hline Dicranum scoparium & & 2 & 3 & 4 & III \\
\hline Geranium robertianum & 2 & 1 & 2 & & III \\
\hline Pseudoscleropodium purum & & 3 & 4 & 5 & III \\
\hline Rhytidiadelphus squarrosus & & 4 & 6 & 2 & III \\
\hline Agrostis capillaris & & & 6 & 4 & II \\
\hline Anthoxanthum odoratum & & & 1 & 2 & II \\
\hline Calluna vulgaris & 2 & & & 2 & II \\
\hline Festuca rubra & & 3 & & 2 & II \\
\hline Hieracium spp. & 1 & & & 3 & II \\
\hline Racomitrium uliginosum & & 2 & & 1 & II \\
\hline Taraxacum sp. & 1 & & & 1 & II \\
\hline Thymus drucei & & 2 & & 5 & II \\
\hline Asplenium trichomanes & & & 1 & & I \\
\hline Campanula rotundifolia & & & & 1 & I \\
\hline Cladonia cf. furcata & & & & 3 & I \\
\hline Galium sterneri & & & & 3 & I \\
\hline Dicranella heteromalla & 1 & & & & I \\
\hline Linum catharticum & & & & 1 & I \\
\hline Luzula pilosa & & & 1 & & I \\
\hline Luzula sylvatica & & & & 1 & I \\
\hline Nardus stricta & & & & 1 & I \\
\hline Pimpinella saxifraga & & & & 3 & I \\
\hline Polystichum aculeatum & & 1 & & & I \\
\hline Potentilla sterilis & & & 1 & & I \\
\hline Porella platyphylla & 1 & & & & I \\
\hline Primula veris & & & & 3 & I \\
\hline Rumex acetosa & & & 1 & & I \\
\hline Saxifraga hypnoides & & & & & I \\
\hline Scabiosa columbaria & & & & 1 & I \\
\hline Vaccinium myrtillus & & & & 1 & I \\
\hline Viola riviniana & & & & \\
\hline Bare ground & & & & & \\
\hline
\end{tabular}


It is currently known from altitudes of 500-610 $\mathrm{m}$ in Craig Cerrig-gleisiad, but historically would have occurred at altitudes of $400+\mathrm{m}$ in Glyn Collwng, and perhaps c.450+ $\mathrm{m}$ in Taf Fechan and Craig Cwm-Du.

Like most hawkweeds it is sensitive to grazing, as shown by the marked increase in Craig Cerrig-gleisiad NNR following the removal of sheep and replacement with extensive summer cattle grazing. In July 2020, stray sheep were noted in the NNR which had grazed many plants on the screes, but following their removal, the plants recovered and some flowered again in September.

There is little information about associated invertebrates. Spittal bugs (presumably the common froghopper Philaenus spumarius) were seen feeding on plants in Craig Cerrig-gleisiad in 2010. The generalist hoverfly Melanostoma mellinum (determined from a photograph by D.J. Clements) was observed feeding in a capitulum in Craig Cerrig-gleisiad in September 2020, and plants were also noted to have adult aphids feeding on the capitula and causing leaf-roll on the leaves.

There are many similarities between the status, ecology and occurrence of $H$. angustatiforme and the Craig Cerrig-gleisiad endemic $H$. neocoracinum (Rich, 2005).

\section{Discussion}

Hieracium angustatiforme is assessed as 'Critically Endangered' under IUCN (2001) threat criteria based on its occurrence in one locality. Although it has declined from four sites to one site, the decline appears to be historic rather than current, though there is little information on which to assess when the decline actually occurred.

Although Critically Endangered, it appears to be under little current threat due to the occurrence on Craig Cerrig-gleisiad NNR/Brecon Beacons Site of Special Scientific Interest (SSSI) with (generally) a favourable grazing regime of extensive cattle grazing, and the population of c.330-430 plants is very healthy. Craig Cerriggleisiad is one of the most important sites for Hieracium in South Wales, with at least 24 species recorded including at least seven rare endemics $(H$. angustatiforme, H. clivicola, H. eustomon, H. neocoracinum, H. pulchrius, H. repandulare and $H$. rubiginosum), all of which are benefiting from the current management. Rare hawkweeds are noted in general in the SSSI site management statement but are not mentioned as features of interest for the SSSI (Natural Resources Wales, 2020); it is recommended these should all be added as features of interest at the next revision.

As a species of principal importance for biodiversity in Wales, it is recommended $H$. angustatiforme should be surveyed every five years to ensure long term survival of the species, and the historic sites should be searched again for possible surviving plants. No seeds are currently held in any seed banks and there are no ex situ collections, so these should be collected as a matter of priority.

\section{Acknowledgements}

I thank the Keepers of herbaria for access to material and libraries, David McCosh for checking the identification of plants and for information from the Hieracium database, David Clements for naming the hoverfly, and Pauline Hill, Paul Smith and Jamie Warren for help with field work. Compilation of the data was partially funded by Natural Resources Wales.

\section{References}

IUCN 2001. IUCN Red list categories and criteria. Version 3.1. Gland: International Union for Conservation of Nature. 
Ley, A. 1909. Brecon and West Yorkshire hawkweeds. Journal of Botany 47: 8-16 and 47-55.

Linton, W.R. 1895. Report of the distributor for 1894. Report of the Botanical Exchange Club of the British Isles 1: 431-464.

Linton, W.R. 1905. An account of the British Hieracia. London: West, Newman \& Co.

McCosh, D.J. \& Rich, T.C.G. 2018. Atlas of British and Irish Hawkweeds (Pilosella Hill and Hieracium L.). 2nd ed. Harpenden: Botanical Society of Britain and Ireland.

Natural Resources Wales 2020. Brecon Beacons Site of Special Scientific Interest. SSSI Citation and Site Management Statement. [online] [accessed 11 October 2020] Available at https://naturalresources.wales.

Pugsley, H.W. 1948. A prodromus of the British Hieracia. Journal of the Linnean Society of London (Botany) 54: 1-356.

Rich, T.C.G. 2005. Conservation of Britain's biodiversity: Hieracium neocoracinum (Asteraceae), Craig Cerrig-gleisiad Hawkweed. Watsonia 25: 283-287.

Rich, T.C.G. 2020. List of vascular plants endemic to Britain, Ireland and the Channel Islands 2020. British \& Irish Botany 2: 169-189.

Rich, T.C.G. \& Smith, P.A. 2007. Conservation of Britain's biodiversity: Hieracium cacuminum (Asteraceae), Summit Hawkweed. Watsonia 26: 463-468.

Rodwell, J.S., ed. 1991-2000. British Plant Communities. Volumes 1-5. Cambridge: Cambridge University Press.

Sell, P.D. \& Murrell, G. 2006. Flora of Great Britain and Ireland, volume 4. Cambridge: Cambridge University Press.

Sell, P.D. \& West, C. 1955. Notes on British Hieracia - I. Watsonia 3: 233-236.

Sell, P.D. \& West, C. 1968. Hieracium L., in Perring, F.H. ed., Critical Supplement to the Atlas of the British flora. London: Botanical Society of the British Isles.

Copyright retained by author(s). Published by BSBI under the terms of the Creative Commons Attribution 4.0 International Public License.

ISSN: $2632-4970$

https://doi.org/10.33928/bib.2021.03.168

\section{Appendix 1. Summary of Hieracium angustatiforme records.}

Craig Cerrig Gleisiad (SN92): Craig Gledsiau, A. Ley, 24 July 1899 (CGE); Cliffs, SN961218, P.D. Sell, 22 June 1953 (CGE; holotype). B.A. Miles, 25 July 1957, $2000 \mathrm{ft}$ (CGE). Top of the gully, B.A. Miles, 5 July 1958 (CGE). Landslip, scarce, 550 m altitude, SN96122198, T.C.G. Rich \& P. Hill, 16 June 2003 (NMW). 27 plants on screes at west end, SN96152202 and c.50 plants, rocks at west end with $H$. neocoracinum, SN96102199, T.C.G. Rich, V. Jones \& B. Burrow, 23 June 2010 (NMW). c.300-400 plants in scree, SN96162200, c.30 plants on slip at top of gully SN96192178, and c.5 plants on rocks $10 \mathrm{~m}$ below top path, SN96382171, T.C.G. Rich, 20 July 2020 and 26 September 2020 (NMW).

Craig Cwm-du (c.SN9521): In the little gorge above Craig Du 'most westerly locality', A. Ley, 24 July 1899 (CGE). 
Glyn Collwng (SO01): Banks, head of Glyn Collwng, A. Ley, 16 August 1893 (CGE). Railway enclosure at the tunnel mouth [SO056171], A. Ley, 15 July 1908 (CGE).

Taf Fechan (SO01): Riverside rocks, near a stream, Cwm Taf Fechan, W.A. Shoolbred, 15 and 16 August 1894 (BM, CGE, NMW). Mountain pastures near a stream, A. Ley, 15 August 1894 (CGE). Mountain pastures, A. Ley, 23 July 1900 (BM, CGE, NMW, OXF). Glen Taf Fechan, A. Ley, 3 August 1900 (BM, CGE, NMW, OXF; Set of British Hieracia no. 150). Upper Taf Fechan, banks of stream, wooded and ferny, A. Ley, 13 July 1908 (CGE).

Cultivated material: Taf Fechan, A. Ley, 13 June 1904 (CGE). Brecon Beacons, A. Ley, June 1908 (NMW). 